\title{
Net Ecosystem Carbon Balance in a North Carolina, USA, Salt Marsh
}

\author{
K. M. Czapla \\ Virginia Institute of Marine Science \\ Iris C. Anderson \\ Virginia Institute of Marine Science \\ C. A. Currin
}

Follow this and additional works at: https://scholarworks.wm.edu/vimsarticles

Part of the Marine Biology Commons

\section{Recommended Citation}

Czapla, K. M.; Anderson, Iris C.; and Currin, C. A., Net Ecosystem Carbon Balance in a North Carolina, USA, Salt Marsh (2020). JGR Biogeosciences, 125(10), e2019JG005509.

doi: 10.1029/2019JG005509

This Article is brought to you for free and open access by the Virginia Institute of Marine Science at W\&M ScholarWorks. It has been accepted for inclusion in VIMS Articles by an authorized administrator of W\&M ScholarWorks. For more information, please contact scholarworks@wm.edu. 


\section{JGR Biogeosciences}

\author{
RESEARCH ARTICLE \\ 10.1029/2019JG005509 \\ Special Section: \\ Carbon Cycling in Tidal \\ Wetlands and Estuaries of the \\ Contiguous United States
}

This article is a companion to Czapla et al. (2020), https://doi.org/10.1029/ 2019JG005238.

Key Points:

- Differences between edge and interior marsh carbon fluxes must be considered when estimating whole marsh rates of carbon accumulation

- Lateral carbon export estimated using respiration rates and tidal water depth was similar to direct measurements

- Fertilization had small effect on net ecosystem carbon balance in the interior but increased carbon loss dramatically on the edge

Supporting Information:

- Supporting Information S1

Correspondence to:

K. M. Czapla,

kmczapla@vims.edu

Citation:

Czapla, K. M., Anderson, I. C., \&

Currin, C. A. (2020). Net ecosystem

carbon balance in a North Carolina,

USA, salt marsh. Journal of Geophysical

Research: Biogeosciences, 125,

e2019JG005509. https://doi.org/

10.1029/2019JG005509

Received 8 OCT 2019

Accepted 28 AUG 2020

Accepted article online 9 SEP 2020

(c)2020. American Geophysical Union. All Rights Reserved.

\section{Net Ecosystem Carbon Balance in a North Carolina, USA, Salt Marsh}

\author{
K. M. Czapla ${ }^{1}$ (D) I. C. Anderson ${ }^{1}$ (D), and C. A. Currin ${ }^{2}$ iD \\ ${ }^{1}$ Virginia Institute of Marine Science, William \& Mary, Gloucester Point, VA, USA, ${ }^{2}$ NOAA Beaufort Laboratory, Beaufort, \\ NC, USA
}

\begin{abstract}
Salt marshes have among the highest carbon (C) burial rates of any ecosystem and often rely on $\mathrm{C}$ accumulation to gain elevation and persist in locations with accelerating sea level rise. Net ecosystem carbon balance (NECB), the accumulation or loss of $\mathrm{C}$ resulting from vertical $\mathrm{CO}_{2}$ and $\mathrm{CH}_{4}$ gas fluxes, lateral $\mathrm{C}$ fluxes, and sediment $\mathrm{C}$ inputs, varies across salt marshes; thus, extrapolation of NECB to an entire marsh is challenging. Anthropogenic nitrogen $(\mathrm{N})$ inputs to salt marshes impact NECB by influencing each component of NECB, but differences in the impacts of fertilization between edge and interior marsh must be considered when scaling up. NECB was estimated for the $0.5 \mathrm{~km}^{2}$ Spartina alterniflora marsh area of Freeman Creek, NC, under control and fertilized conditions at both interior and edge berm sites. Annual $\mathrm{CO}_{2}$ fluxes were nearly balanced at control sites, but fertilization significantly increased net $\mathrm{CO}_{2}$ emissions at edge sites. Lateral $\mathrm{C}$ export, modeled using respiration rates, represented a significant $\mathrm{C}$ loss that increased with fertilization in both edge and interior marsh. Sediment $\mathrm{C}$ input was a significant $\mathrm{C}$ source in the interior, nearly doubling with fertilization, but represented a small source on the edge. When extrapolating $\mathrm{C}$ exchanges to the entire marsh, including edge which comprised $17 \%$ of the marsh area, the marsh displayed net loss of $\mathrm{C}$ despite a net $\mathrm{C}$ gain in the interior. Fertilization increased net $\mathrm{C}$ loss fivefold. Extrapolation of NECB to whole marshes requires inclusion of $\mathrm{C}$ fluxes for both edge and interior marsh.
\end{abstract}

Plain Language Summary Salt marsh ecosystems rely on carbon accumulation to increase elevation and survive sea level rise. The amount of carbon accumulated in a marsh is the net result of carbon dioxide emissions to the atmosphere, fixation of carbon by photosynthesis, export of dissolved carbon to the creek, and accumulation of organic carbon in sediments deposited on the surface. Because each component varies between edge and interior marsh, it is challenging to estimate carbon accumulation for a whole marsh system. It is not currently known how increasing nitrogen pollution impacts carbon accumulation for a whole marsh. To find out, we compared measurements of carbon accumulation in fertilized and unfertilized plots in the edge and interior of a salt marsh at Freeman Creek, North Carolina, USA. Overall, the marsh gained carbon in the interior but lost carbon on the edge, leading to a loss of about $50,000 \mathrm{~kg} \mathrm{C}_{\text {year }}{ }^{-1}$ across the $0.5 \mathrm{~km}^{2}$ marsh area. However, under fertilized conditions, Freeman Creek marsh carbon loss increased nearly fivefold overall as a result of the large increase in carbon loss from the edge marsh. This study shows that increasing nitrogen pollution in coastal waters will cause increasing net carbon loss in marshes.

\section{Introduction}

Salt marshes, which represent a large reservoir of carbon (C), have among the highest rates of $\mathrm{C}$ burial per unit area of any ecosystem (Duarte et al., 2005). The top meter of sediment in North American salt marshes has been estimated to contain $1,886 \pm 1,046 \mathrm{Tg} \mathrm{C}$ and accumulates $9 \pm 5 \mathrm{Tg} \mathrm{C}$ annually (Windham-Myers et al., 2018). Whereas these systems do not comprise a significant component of the global C budget due to their small and declining total area (Ouyang \& Lee, 2014), they may strongly influence local waters through the import of particulate organic $\mathrm{C}$ and export of dissolved organic and inorganic $\mathrm{C}$ (DOC and DIC) (Childers et al., 2002).

These salt marsh C reservoirs are currently threatened by accelerating sea level rise (SLR). If salt marshes do not accrete faster than the local rate of SLR, they will destabilize, potentially releasing buried C to adjacent coastal waters or atmosphere. However, salt marshes have been shown to be surprisingly resilient to SLR (Kirwan et al., 2016), which may enhance marsh C burial rates through increased accretion rates (Kirwan 
\& Mudd, 2012; Rogers et al., 2019). Carbon may accumulate through plant production and/or by trapping and deposition of sediment by aboveground biomass (AGB); however, $\mathrm{C}$ is also lost due to plant and microbial respiration. Salt marsh net ecosystem carbon balance (NECB), which results from vertical $\mathrm{CO}_{2}$ exchanges with the atmosphere, lateral dissolved $\mathrm{C}$ exchanges, and allochthonous sediment $\mathrm{C}$ inputs (Chapin et al., 2006), is an estimator of total $\mathrm{C}$ accumulation or loss in the marsh. Due to the inherent challenges in estimating each of these fluxes, little is known about the spatial heterogeneity and drivers of salt marsh NECB.

Vertical exchanges of $\mathrm{CO}_{2}$ and $\mathrm{CH}_{4}$, the most commonly measured components of NECB, may be measured using either static chambers or eddy covariance towers. Gross primary production (GPP) takes up atmospheric $\mathrm{CO}_{2}$ while respiration $(\mathrm{R})$ performed by both plants and sediment microbial communities simultaneously releases $\mathrm{CO}_{2}$ to the atmosphere. The balance of these two processes, net ecosystem exchange (NEE), may represent a net loss or gain of $\mathrm{C}$, depending on light level, temperature, AGB, nutrient availability, pore water sulfide concentrations, and other variables that drive $\mathrm{R}$ and $\mathrm{GPP}$. Vertical $\mathrm{CH}_{4}$ fluxes are typically small in salt marshes because sulfate in seawater inhibits methanogenesis (Poffenbarger et al., 2011).

When a marsh is inundated by tidal water, much of the $\mathrm{CO}_{2}$ produced by $\mathrm{R}$ dissolves as DIC, which is exported laterally along with DOC produced by GPP or leached from plant biomass. Lateral C fluxes are thought to be a significant term in marsh NECB budgets (Childers et al., 2002; Neubauer \& Anderson, 2003; Z. A. Wang et al., 2016). According to the much-debated Outwelling Hypothesis (Childers et al., 2002; Nixon, 1980; Odum, 1980), C exported from marshes may support secondary production in adjacent coastal ecosystems. Tidal wetlands have been estimated to be the source of about $35 \%$ of TOC in estuaries on the east coast of the United States (Herrmann et al., 2015).

Because of the organic $\mathrm{C}$ present in suspended sediments in tidal water, allochthonous $\mathrm{C}$ may represent a significant portion of a salt marsh's total NECB. The rate of sediment $\mathrm{C}$ accumulation depends on the $\mathrm{C}$ content in suspended sediments and the rate of sediment deposition, which varies depending on tidal amplitude, elevation, inundation duration and depth, suspended sediment concentrations (Friedrichs \& Perry, 2001), and Spartina alterniflora AGB (Morris et al., 2002). In locations where fertilization increases AGB and tidal water contains ample sediment concentrations, fertilization increases allochthonous $\mathrm{C}$ accumulation (Morris, Shaffer, \& Nyman, 2013) and elevation (Davis et al., 2017). While both mineral and organic sediments accumulate in marshes, organic material is often responsible for the majority of the vertical accretion in marshes on the U.S. east coast (Morris et al., 2016; Neubauer, 2008).

Heterogeneous physical and chemical characteristics within and across salt marsh sites drive spatial heterogeneity of NEE, lateral $\mathrm{C}$ export, and sediment $\mathrm{C}$ deposition and, therefore, will drive spatial variation of NECB. Elevation is one major characteristic that varies across marsh surfaces, driving variation in pore water chemistry. Typical marsh morphology often consists of a high berm on the edge adjacent to the tidal creek due to a history of high sediment deposition rates (Temmerman et al., 2003) backed by a lower interior marsh with elevation gradually increasing toward the upland. Rapid flushing of sediment with oxic creek water (Gardner, 2005; Harvey et al., 1995) causes lower accumulation of metabolic products such as $\mathrm{H}_{2} \mathrm{~S}$ and $\mathrm{NH}_{4}{ }^{+}$in pore water on the edge than in the interior (Czapla et al., 2020; Howes \& Goehringer, 1994). The differences in pore water chemistry across these marsh subhabitats will give rise to distinct $\mathrm{C}$ and $\mathrm{N}$ cycling dynamics. Differences in $\mathrm{C}$ fluxes between edge and interior marsh may be important to consider when scaling NECB estimates to whole marsh areas.

Nitrogen availability, which is increasing in many salt marshes as a result of anthropogenic inputs (Hopkinson et al., 2012; Pardo et al., 2011), is likely to have a strong impact on each component of salt marsh NECB and thus NECB itself. Studies have shown that fertilization increases C accumulation through aboveground production and sediment input (Anisfeld \& Hill, 2012; Darby \& Turner, 2008; Davis et al., 2017; McFarlin et al., 2008; Mendelssohn, 1979; Morris, Shaffer, \& Nyman, 2013; Valiela, 2015) but also increases $\mathrm{C}$ losses through net $\mathrm{CO}_{2}$ emissions (Caplan et al., 2015; J. Wang et al., 2013) and decreased belowground production (Darby \& Turner, 2008; Deegan et al., 2012; Graham \& Mendelsshon, 2016). However, it is unknown whether increasing $\mathrm{N}$ has a positive or negative effect on salt marsh NECB. Czapla et al. in a companion paper in this issue pointed out that fertilization effects on $\mathrm{C}$ fluxes differ across marsh sites due to location-specific physical and chemical characteristics, and this heterogeneity in responses to fertilization may complicate the relationship between salt marsh $\mathrm{N}$ availability and NECB. While several studies have reported an 
increase in AGB and net $\mathrm{CO}_{2}$ emissions with fertilization, other studies have reported no effect on AGB (Davis et al., 2017; Johnson et al., 2016) and NEE (Geoghegan et al., 2018) at certain sites. Belowground biomass (BGB) has been reported to either increase (Morris, Sundberg, \& Hopkinson, 2013; Wigand et al., 2014), decrease (Darby \& Turner, 2008; Deegan et al., 2012; Graham \& Mendelsshon, 2016), or remain the same (Davis et al., 2017) in response to fertilization. Accumulation of pore water sulfide in interior marshes may determine how salt marshes respond to fertilization. Sulfide has been shown to inhibit plant uptake of $\mathrm{NH}_{4}{ }^{+}$(Bradley \& Morris, 1990). In the same companion paper, Czapla et al. hypothesized that the inhibition of plant $\mathrm{NH}_{4}{ }^{+}$uptake in the presence of pore water sulfide reduced the potential impact of fertilization on NECB in interior marshes. However, in edge marshes tidal flushing of pore water removed sulfide and resulted in an increased response of NECB to fertilization. In addition, the response of sediment deposition to fertilization has been observed to vary across studies depending on suspended sediment concentrations and the response of AGB to fertilization (Morris, Shaffer, \& Nyman, 2013).

The objectives of this study were to (1) determine per $\mathrm{m}^{2}$ differences in NEE, lateral $\mathrm{C}$ export, sediment $\mathrm{C}$ input, and NECB between edge marsh and interior marsh for both natural and fertilized conditions and (2) determine the effect of fertilization on lateral $\mathrm{C}$ export, sediment $\mathrm{C}$ input, and NECB for the total marsh area, taking differences in edge and interior into account. We hypothesized that edge marsh would have greater $\mathrm{C}$ losses than the interior marsh on an annual basis; fertilization would result in greater $\mathrm{C}$ loss overall, and the effect of fertilization on edge NECB would be greater than on interior NECB. We expected that accounting for differences in edge versus interior $\mathrm{C}$ fluxes would significantly impact rates scaled to the whole marsh area. To our knowledge, this study is the first mass balance calculation of salt marsh NECB on an annual time scale.

\section{Materials and Methods}

\subsection{Experimental Site}

Freeman Creek (FC) is a small tidal creek along the Intracoastal Waterway on Camp Lejeune Marine Corps Base, NC (Figure 1, 34 $35^{\prime} 52.8^{\prime \prime} \mathrm{N}, 77^{\circ} 19^{\prime} 37.2^{\prime \prime} \mathrm{W}$ ). It has a typical salinity range of 30-35, annual average tidal amplitude of $0.83 \mathrm{~m}$, and $0.50 \mathrm{~km}^{2}$ of $S$. alterniflora-dominated marshes. This study compared sites at FC marsh in the interior and along the creek edge. Interior plots were approximately 70-100 $\mathrm{m}$ from the creek edge and were within 0 to $0.1 \mathrm{~m}$ above sea level, whereas the edge plots were located on the top of a berm within $5 \mathrm{~m}$ of the creek and 0.2 to $0.3 \mathrm{~m}$ above sea level.

\subsection{Experimental Design}

Three replicate control-fertilized plot pairs were established on both the edge and interior of FC, maintaining at least $1 \mathrm{~m}$ between pairs. Aluminum collars $(0.9 \mathrm{~m} \times 0.9 \mathrm{~m})$ with drainage holes were permanently installed in each plot at the beginning of the experiment as a base to set chambers on. A solid mixture of $\mathrm{NH}_{4} \mathrm{NO}_{3}$ and $\mathrm{P}_{2} \mathrm{O}_{5}\left(30\right.$ mol N year ${ }^{-1}$ and $15 \mathrm{~mol} \mathrm{Pyear}^{-1}$ ) was distributed evenly by hand at low tide on plots randomly chosen within each pair for fertilization. This fertilization rate was selected because it has been used in several previous studies (Davis et al., 2017; Morris et al., 2002; Valiela, 2015). Greater natural N loading has been observed at other marsh sites (Wigand et al., 2009). Fertilization was performed on the dates indicated in Supporting Information Table S2, and seasonal $\mathrm{CO}_{2}$ and $\mathrm{CH}_{4}$ flux measurements took place at least 1 month after each fertilization.

\subsection{Spatial Analysis}

ArcGIS was used to quantify the total area of S. alterniflora marsh classified as "edge" versus "interior." Edge marsh was defined as the marsh area within $5 \mathrm{~m}$ of the creek, so that much of the edge included the highelevation berm area, which was approximately $5 \mathrm{~m}$ wide. The $S$. alterniflora area was broken down into elevation categories for every $0.1 \mathrm{~m}$ elevation change, and the total area of each elevation category was quantified for edge and interior separately. Elevation raster data were derived from 2013 Camp Lejeune Marine Corps Base Lidar data. The resulting areas were used to spatially extrapolate edge and interior NEE and lateral $\mathrm{C}$ export to their respective elevations. 


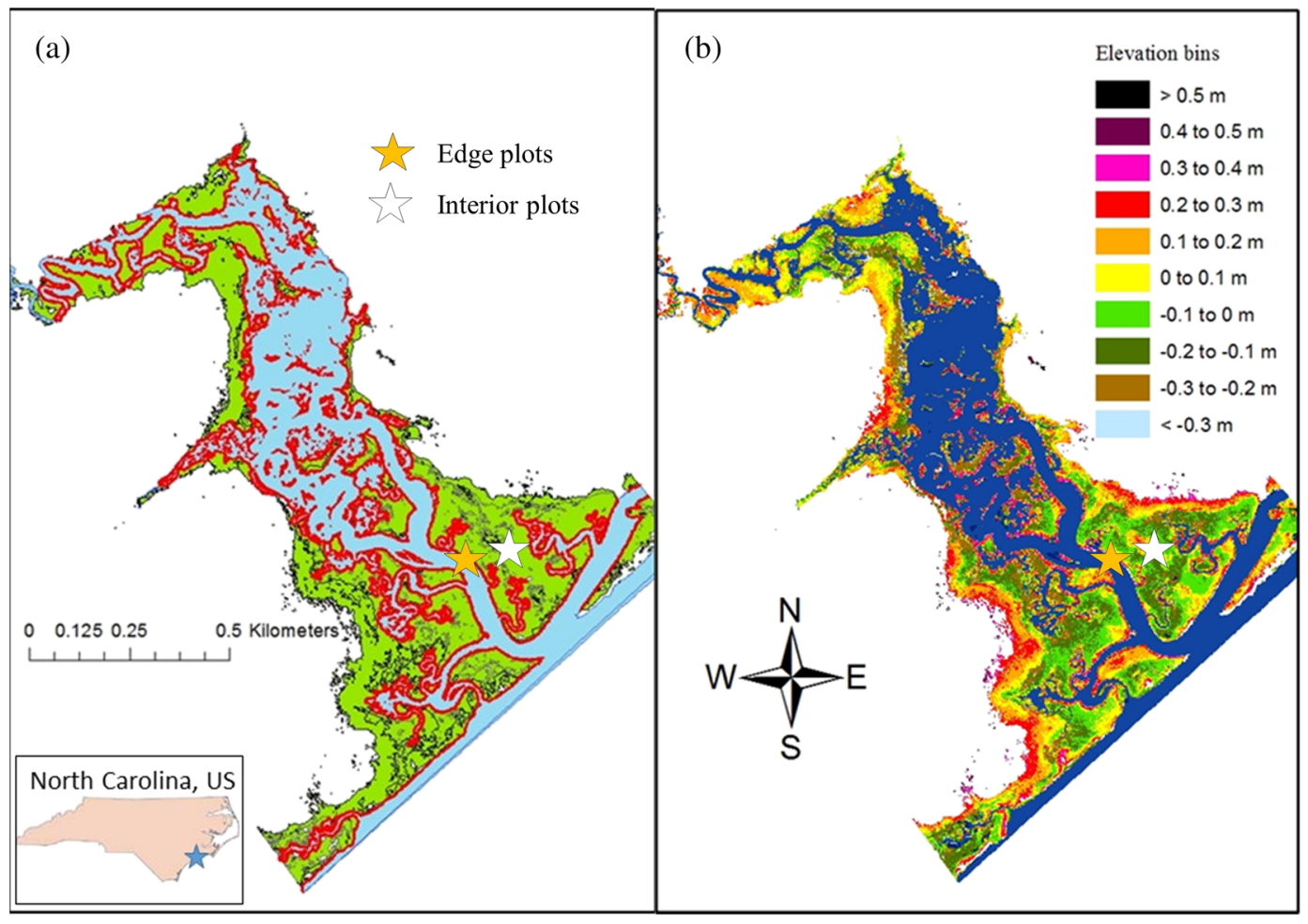

Figure 1. Maps of Freeman Creek Spartina alterniflora area $\left(34^{\circ} 35^{\prime} 52.8^{\prime \prime} \mathrm{N}, 77^{\circ} 19^{\prime} 37.2^{\prime \prime} \mathrm{W}\right.$ ) showing (a) edge (red) and interior (green) areas of S. alterniflora marsh; stars indicate the location of edge and interior plots, and (b) elevations (NAVD88) binned by $0.1 \mathrm{~m}$ categories. Blue represents creek area. Analysis performed in ArcGIS.

\subsection{Vertical C Flux}

NEE was modeled throughout the year based on chamber measurements of $\mathrm{CO}_{2}$ fluxes, PAR, and temperature and corrected for the effects of tidal inundation depth relative to stem height (companion paper by Czapla et al. and supporting information). $\mathrm{CH}_{4}$ fluxes were measured with a Los Gatos Greenhouse Gas Analyzer simultaneously with $\mathrm{CO}_{2}$ fluxes. To account for varying elevations across the marsh, the $\%$ of S. alterniflora stem height inundated per hour was estimated based on water depth at the midpoint of each elevation category. The resulting annual flux for each elevation category was multiplied by the total area of edge or interior in each respective elevation category and was summed to extrapolate to the entire marsh area.

\subsection{Lateral C Flux}

\subsubsection{Groundwater Flux}

Three $50 \mathrm{~cm}$ deep piezometers were installed on the edge of FC marsh and sampled seasonally for groundwater DOC and DIC. Piezometers were flushed with $\mathrm{N}_{2}$ gas prior to sampling to remove reactive gases and pumped to flush out stagnant pore water. DOC samples were filtered in the field into scintillation vials (combusted prior to sampling at $500^{\circ} \mathrm{C}$ for $5 \mathrm{hr}$ ) with $0.45 \mu \mathrm{m}$ polyethylsulfone syringe filters, stored frozen, and analyzed on a Shimadzu TOC-V analyzer. DIC samples were collected without filtering in $8 \mathrm{ml}$ Hungate tubes spiked with $8 \mu \mathrm{l}$ of saturated $\mathrm{HgCl}_{2}$ solution and analyzed within 30 days of collection with a Li-Cor 6252 infrared $\mathrm{CO}_{2}$ analyzer by injecting $100 \mu \mathrm{l}$ of sample into $0.05 \mathrm{M} \mathrm{H}_{2} \mathrm{SO}_{4}$ sparged with $\mathrm{N}_{2}$ gas as described in Neubauer and Anderson (2003).

Annual groundwater drainage volume per meter of creekbank length was calculated at FC by Lettrich (2011) using Darcy's law, which derives groundwater flow rate from hydraulic head and conductivity. Annual average concentrations of pore water DOC and DIC were multiplied by the pore water drainage volume per meter of creekbank per year and the total length of creekbank at FC to calculate lateral groundwater DIC and DOC fluxes. 


\subsubsection{Tidal Lateral Flux}

Respiration measured as $\mathrm{CO}_{2}$ emissions in dark chambers was used as a proxy for DIC export using the formula:

$$
\text { Lateral DIC export }=\mathrm{R}_{\mathrm{M}} * \mathrm{P}_{\mathrm{S}}
$$

where $\mathrm{R}_{\mathrm{M}}=$ modeled hourly $\mathrm{R}$ based on chamber measurements and $\mathrm{P}_{\mathrm{S}}=$ percentage of total average stem height submerged in tidal water.

Lateral DIC export rates were modeled using this formula and summed to estimate annual lateral DIC export. This calculation was based on an observed negative linear relationship (Zawatski, 2018) between the proportion of plant stem submerged and the $\mathrm{CO}_{2}$-derived $\mathrm{R}$, which is zero at $100 \%$ plant stem submersion. Average stem heights used were specific to each plot. We assumed that the same rate of respiration occurs during inundated and non-inundated periods but the product of R is DIC rather than $\mathrm{CO}_{2}$ gas during inundation. Therefore, the amount of DIC produced by R during inundation was calculated as the difference between the modeled $\mathrm{CO}_{2}$ fluxes before and after inundation correction.

To test the validity of deriving lateral DIC fluxes from respiration rates as described above, the respirationderived DIC fluxes were compared to the DIC fluxes estimated based on DIC concentrations in water overlying the marsh for two individual tidal cycles during different seasons. For each tidal cycle, three replicate DIC and DOC samples were taken from the surface tidal creek water at slack low tide before the marsh was inundated, and overlying marsh water was sampled during slack high tide at six locations across the marsh. Samples were taken and analyzed in the same manner as previously described for the groundwater lateral flux. The lateral DIC flux for a single tidal cycle was calculated as

$$
\text { Measured DIC lateral flux }=\left(\mathrm{DIC}_{\mathrm{marsh}}-\mathrm{DIC}_{\mathrm{creek}}\right) * \mathrm{~V}_{\text {marsh }}
$$

where DIC marsh is the concentration of DIC in water overlying the marsh; DIC $_{\text {creek }}$ is the concentration of DIC in the creek; and $\mathrm{V}_{\text {marsh }}$ is the volume of water overlying the marsh, based on average elevation, water height, and total area of marsh.

Lateral DOC fluxes were calculated in the same way based on the concentration of DOC in samples. The average ratio of these DIC and DOC lateral flux calculations was used to calculate the annual DOC lateral flux from the modeled DIC lateral flux as follows:

Annual DOC lateral flux $=$ modeled DIC lateral flux * (average measured DOC: DIC lateral flux $)$

\subsection{Sediment C Deposition}

Sediment deposition was measured on the marsh surface using marker horizons established in three control and two fertilized plots in FC interior. The sediment deposition depth above the marker horizon was sampled with a cryocore every 3 months, and a fresh marker horizon was laid down after each measurement. Percent $\mathrm{C}$ content by mass (\% C) and bulk density were measured seasonally in the top $2 \mathrm{~cm}$ of $2.2 \mathrm{~cm}$ diameter cores. FC interior marsh sediment were used to calculate $\mathrm{C}$ content in accreted sediment. Percent $\mathrm{C}$ was measured on a Flash EA1112 elemental analyzer, and bulk density was calculated from sediments dried in a $60^{\circ} \mathrm{C}$ oven for 2 weeks and weighed. $\mathrm{C}$ input along the $\mathrm{FC}$ edge was predicted from $\mathrm{FC}$ interior marker horizon-measured rates by assuming a linear relationship between flood duration and log sediment deposition, which has been observed widely across salt marshes (Cahoon \& Reed, 1995; Darke \& Megonigal, 2003; Friedrichs \& Perry, 2001).

\subsection{Net Ecosystem Carbon Balance}

NECB was determined based on a mass balance of $\mathrm{C}$ fluxes, as shown in the following equation published in Chapin et al. (2006):

$$
\mathrm{NECB}=-\mathrm{NEE}+\mathrm{F}_{\mathrm{CO}}+\mathrm{F}_{\mathrm{CH} 4}+\mathrm{F}_{\mathrm{VOC}}+\mathrm{F}_{\mathrm{DIC}}+\mathrm{F}_{\mathrm{DOC}}+\mathrm{F}_{\mathrm{PC}}
$$

where $\mathrm{NEE}=$ net ecosystem exchange; $\mathrm{F}_{\mathrm{CO}}=$ net carbon monoxide $(\mathrm{CO})$ absorption; $\mathrm{F}_{\mathrm{CH} 4}=$ net $\mathrm{CH}_{4}$ consumption; $\mathrm{F}_{\mathrm{VOC}}=$ net volatile organic $\mathrm{C}(\mathrm{VOC})$ absorption; $\mathrm{F}_{\mathrm{DIC}}=$ net dissolved inorganic $\mathrm{C}(\mathrm{DIC})$ input 
to the ecosystem; $\mathrm{F}_{\mathrm{DOC}}=$ net dissolved organic $\mathrm{C}(\mathrm{DOC})$ input; and $\mathrm{F}_{\mathrm{PC}}=$ net lateral transfer of particulate (nondissolved, nongaseous) $\mathrm{C}$ into the ecosystem.

Here we calculate NECB using this equation, assuming that CO and VOC fluxes are negligible relative to the other large salt marsh fluxes. VOC fluxes are typically very low unless large industrial discharges are present at a site (Wakeham et al., 1982).

\subsection{Statistics}

A three-way analysis of variance (ANOVA) with factors of season, treatment, and location was performed in $\mathrm{R}$ (R Core Team, 2014) to determine statistical differences in plot-level methane fluxes. Mixed-effect models with treatment and location as fixed effects and plot pair as a random effect were performed with the lme4 package (Bates et al., 2015) in $\mathrm{R}$ to assess significant differences in fluxes per $\mathrm{m}^{2}$. Modeled and directly measured lateral $\mathrm{C}$ fluxes were tested for statistical differences using a two-tailed two-sample $t$ test. Fluxes spatially extrapolated to the entire marsh were tested for differences between fertilized and control treatments using a paired $t$ test.

\section{Results}

\subsection{FC Spatial Analysis}

ArcGIS analysis of FC salt marshes revealed that of the $0.50 \mathrm{~km}^{2}$ total S. alterniflora area, $0.09 \mathrm{~km}^{2}$ or $17 \%$ of the area was within $5 \mathrm{~m}$ of the tidal creek and thus defined as "edge" area. Binning elevations into categories of $0.1 \mathrm{~m}$ ranges (Table $\mathrm{S} 1$ ) revealed that $75 \%$ of the total area was within -0.2 and $0.2 \mathrm{~m}$ above sea level (NADV88); however, the edge area skewed toward greater elevations, with greatest edge area within $0.1-0.2$ and $0.2-0.3 \mathrm{~m}$ elevation categories.

\subsection{Vertical C Fluxes}

\subsubsection{Vertical $\mathrm{CO}_{2}$ Flux}

$\mathrm{NEE}$ at control sites was in close balance at both the edge and interior; however, fertilization resulted in net $\mathrm{CO}_{2}$ emissions at both sites. Both R and GPP were greater on the edge than the interior, and both were stimulated by fertilization (see companion paper Czapla et al., 2020). Edge control and fertilized NEE were -82.7 and $694.7 \mathrm{~g} \mathrm{CO}_{2} \mathrm{~m}^{-2}$ year ${ }^{-1}$, respectively, but interior control and fertilized NEE were 18.5 and $216.5 \mathrm{~g} \mathrm{CO}_{2} \mathrm{~m}^{-2}$ year $^{-1}$, respectively.

NEE was significantly greater in fertilized than control plots at the edge $\left(p=7.5 \times 10^{-5}\right)$, but no significant difference was observed in the interior (Figure 2). Once fluxes were extrapolated to the total edge and interior areas at $\mathrm{FC}$, the total marsh area emitted $3.7 \times 10^{2} \mathrm{~kg} \mathrm{CO}_{2}$ year ${ }^{-1}$ under control conditions and $1.5 \times 10^{5} \mathrm{~kg} \mathrm{CO}_{2}$ year $^{-1}$ under fertilized conditions. NEE extrapolated to the total Freeman marsh was significantly higher for fertilized marsh $(p=0.023)$. If the greater NEE rates along the fertilized edge had been ignored for spatial extrapolation, the NEE of the total fertilized marsh area would have been underestimated by $38 \%$.

\subsubsection{Vertical $\mathrm{CH}_{4}$ Flux}

$\mathrm{CH}_{4}$ fluxes (Figure 3) ranged between 0 and $6 \mathrm{mg} \mathrm{CH}_{4} \mathrm{~m}^{-2}$ day ${ }^{-1}$, more than 3 orders of magnitude lower than daily respiration rates (ranging from 470 to $13,460 \mathrm{mg} \mathrm{CO}_{2} \mathrm{~m}^{-2} \mathrm{day}^{-1}$ ). A three-way ANOVA indicated that $\mathrm{CH}_{4}$ fluxes were not statistically different across locations and treatments, but winter $\mathrm{CH}_{4}$ fluxes were significantly lower than fall $\left(p=1.27 \mathrm{e}^{-5}\right)$, spring $\left(p=3.9 \mathrm{e}^{-5}\right)$, and summer $\left(p=7 \mathrm{e}^{-7}\right)$ fluxes. Because the magnitudes of $\mathrm{CH}_{4}$ fluxes were negligible compared to $\mathrm{CO}_{2}$ for a marsh carbon budget, $\mathrm{CH}_{4}$ was not temporally or spatially extrapolated for the annual NECB calculation.

\subsection{Lateral DIC/DOC Flux}

For the entire marsh area, the modeled lateral DIC flux varied widely per tidal cycle, ranging from 0 to $2,000 \mathrm{~kg}_{\text {tidal }}$ cycle $^{-1}$ (Figure 4). Lateral DIC export from fertilized marsh was consistently greater than export from unfertilized sites for the same tidal cycles. The greatest fluxes corresponded with long inundation periods and high water levels in the fall, but the lowest fluxes occurred during the winter. According to mixed-effects model analysis, the annual tidal lateral DIC and DOC fluxes estimated from modeled $\mathrm{CO}_{2}$ fluxes (Figure 5) were significantly greater in control plots on the edge than in the interior $(p=0.02)$ but significantly greater with fertilization in both locations $\left(p=2.2 \times 10^{-16}\right)$. The annual tidal lateral DIC and DOC 


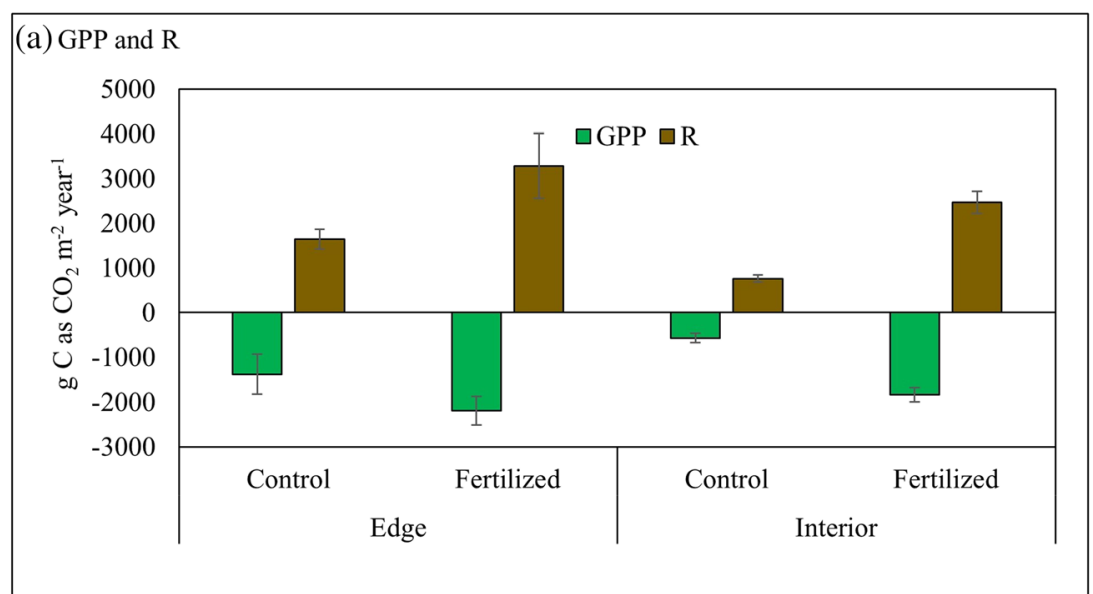

(b) NEE

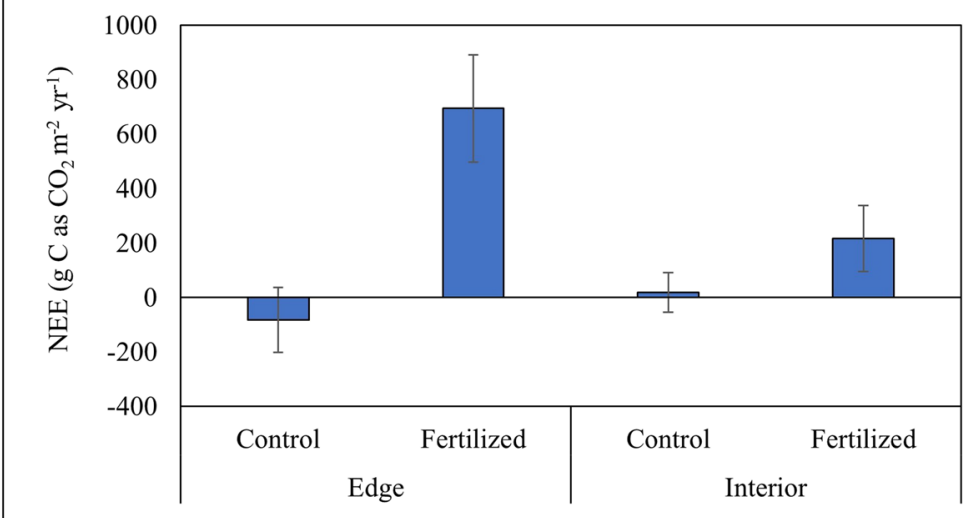

Figure 2. Annual (a) GPP and R and (b) NEE fluxes from edge and interior Freeman marsh areas. Error bars represent standard error of the mean of the three triplicate plots.

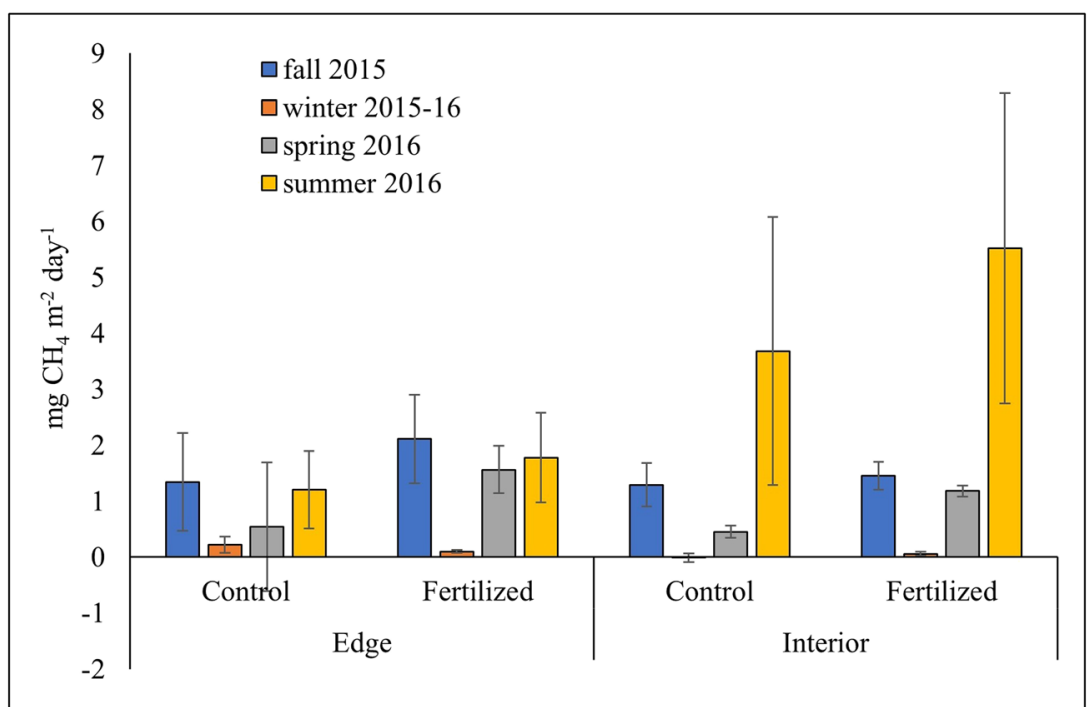

Figure 3. Daily methane fluxes measured by chambers in Freeman Creek plots. Error bars represent standard error of the mean of the three triplicate plots. 


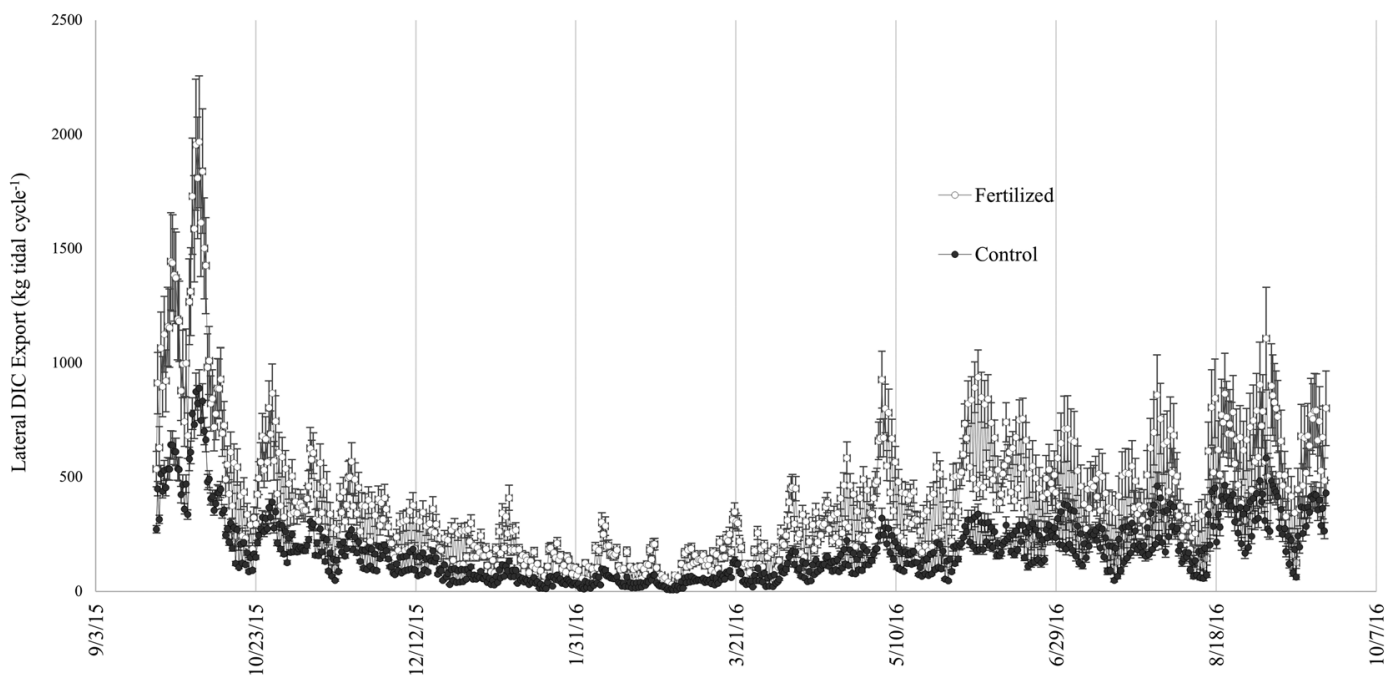

Figure 4. Lateral DIC export per tidal cycle in control and fertilized treatments modeled from chamber-measured respiration rates extrapolated to the total marsh area. Error bars represent standard error of the mean of the three triplicate plots.

fluxes for the total marsh area were $1.26 \times 10^{5} \mathrm{~kg}$ for the control treatment and $2.73 \times 10^{5} \mathrm{~kg} \mathrm{year}^{-1}$ for the fertilized treatment. Control and fertilized lateral $\mathrm{C}$ fluxes were significantly different $(p=0.007)$. Ignoring greater lateral fluxes from edge marsh would result in a $10 \%$ underestimation of the lateral tidal flux from the total marsh area. The groundwater lateral DIC flux was $20.1 \times 10^{3} \mathrm{~kg} \mathrm{year}^{-1}, 2$ orders of magnitude lower than the tidal lateral flux. The groundwater lateral DOC flux was $1.2 \times 10^{3} \mathrm{~kg} \mathrm{year}^{-1}$, an order of magnitude lower than the lateral DIC flux in tidal water.

DIC export modeled using $\mathrm{CO}_{2}$ respiration rates were similar to those based on concentrations of DIC measured during slack flood during two different seasons (Table 1). While the DIC export during summer was more than three times greater than the DIC export during spring for both modeled and measured methods, the modeled export was consistently about $60 \%$ of the measured export. There was no statistical difference between measured and modeled lateral DIC export for both April $(p=0.26)$ and August $(p=0.07)$ tidal cycles. The measured DOC export was on average $78 \%$ of the measured DIC export per tidal cycle.

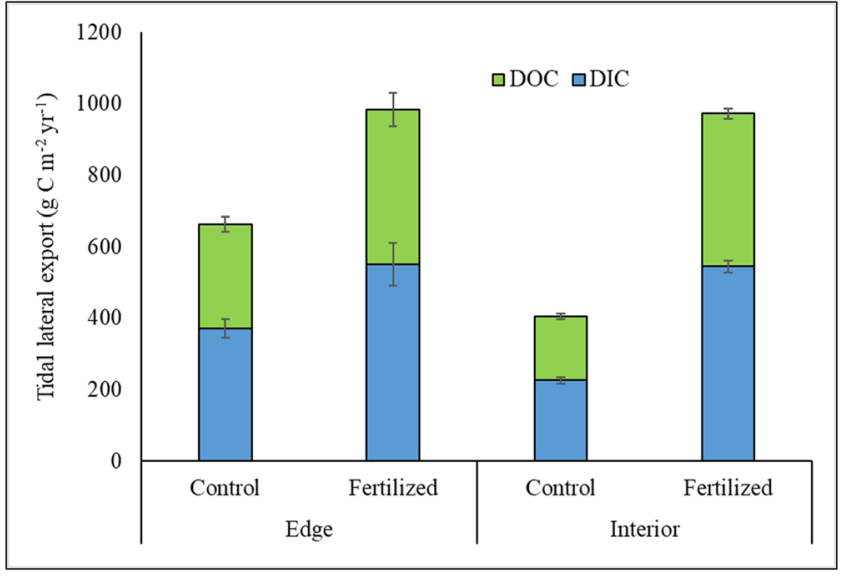

Figure 5. Lateral DIC and DOC export from Freeman Creek (predicted from chamber-measured R and tidal water depth). Error bars represent standard error of the mean of the three triplicate plots.

\subsection{Sediment Carbon Deposition}

Marker horizons in Freeman interior accreted $3.7( \pm 0.4)$ and 7.8 $( \pm 3.3) \mathrm{cm}$ sediment annually in control and fertilized treatments, respectively. Average values of 0.289 and $0.274 \mathrm{~g} \mathrm{~cm}-{ }^{3}$ bulk density for control and fertilized treatments and an average of $4.5 \% \mathrm{C}$ by mass in surface sediment were used for all locations and treatments. The interior was estimated to have accumulated 507.2 and $1,016 \mathrm{~g}$ $\mathrm{C} \mathrm{m}^{-2}$ year $^{-1}$ under control and fertilized conditions, respectively. Accumulation of $\mathrm{C}$ through sediment deposition (Figure 6) was an order of magnitude lower on the edge than in the interior. The linear relationship between log sediment deposition and flood duration was expressed as $y=0.0492 x$ for the control treatment and $y=0.0547 x$ for the fertilized treatment. Calculation of sediment deposition based on this linear relationship yielded rates of $59.0 \mathrm{~g} \mathrm{C} \mathrm{m}^{-2}$ year $^{-1}$ at control sites and $93.2 \mathrm{~g} \mathrm{C} \mathrm{m}^{-2}$ year $^{-1}$ at fertilized sites. Fertilization doubled sediment $\mathrm{C}$ deposition in the interior. Once extrapolated to the entire marsh area, Freeman marsh accumulated $2.14 \times 10^{5} \mathrm{~kg}$ sediment $\mathrm{C}$ year $^{-1}$ under control conditions but $4.27 \times 10^{5} \mathrm{~kg}$ sediment $\mathrm{C}$ year $^{-1}$ under fertilized conditions. If the interior flux rates were 
Table 1

Comparison of Lateral DIC Flux $\left(\mathrm{g} \mathrm{m}^{-2}\right.$ Tidal Cycle $\left.{ }^{-1}\right)$ Measured Directly Versus Predicted by $R$ and Tidal Water Depth

\begin{tabular}{lcccc}
\hline Date & $\begin{array}{c}\text { Measured } \\
\text { export }\end{array}$ & $\begin{array}{c}\text { R-predicted } \\
\text { export }\end{array}$ & $\begin{array}{c}\text { DIC R-predicted: } \\
\text { measured (\%) }\end{array}$ & $\begin{array}{c}\# \\
\text { samples }\end{array}$ \\
\hline $4 / 16 / 2016$ & $0.34(0.08)$ & $0.21(0.01)$ & 60.43 & 6 \\
$8 / 26 / 2016$ & $1.07(0.06)$ & $0.62(0.24)$ & 58.36 & 6 \\
\hline
\end{tabular}

Note. Calculations described in section 2.5.2. Standard errors are in parentheses. Dates are formatted as MM/DD/YYYY. applied to the entire marsh area, the resulting sediment $\mathrm{C}$ deposition would be overestimated by about $20 \%$ for both natural and fertilized treatments.

\subsection{Net Ecosystem Carbon Balance}

NECB was calculated based on the Chapin et al. (2006) equation as shown in Table 2.

Based on the mass balance of each of the fluxes considered in this study, the marsh lost $520.5 \mathrm{~g} \mathrm{C} \mathrm{m}^{-2}$ on the edge but gained $83.5 \mathrm{~g}$

$\mathrm{C} \mathrm{m}^{-2}$ in the interior (Figure 7). Fertilization increased $\mathrm{C}$ loss on the edge about threefold $(p=0.0022)$ but did not significantly affect the NECB in the interior $(p=0.61)$. However, the average interior NECB shifted from a net $\mathrm{C}$ gain to a net $\mathrm{C}$ loss with fertilization. Edge and interior NECB were significantly different for both control $(p=0.027)$ and fertilized $(p<0.0001)$ conditions. After scaling up to the entire marsh area (Figure 8), FC marsh was estimated to lose $3.2 \times 10^{4} \mathrm{~kg} \mathrm{C} \mathrm{year}^{-1}$ under control conditions but $2.3 \times 10^{5} \mathrm{~kg} \mathrm{C}$ year $^{-1}$ under fertilized conditions. However, if edge fluxes were ignored, total marsh area NECB would show a net $\mathrm{C}$ gain of $4.14 \times 10^{4} \mathrm{~kg} \mathrm{C}$ year $^{-1}$ instead of net loss under natural conditions and would decrease the estimated $\mathrm{C}$ losses under fertilized conditions. A paired $t$ test indicated that total marsh NECB was significantly different between control and fertilized treatments $(p=0.003)$.

\section{Discussion}

We observed a clear difference in NECB between edge and interior marsh and confirmed that spatial heterogeneity of NECB must be considered for accurate extrapolation to whole marsh systems. While the consideration of heterogeneity between edge and interior in flux rates represents an improvement over many past extrapolation methods, extrapolations from plot measurements to whole marsh estimates continue to have shortcomings and rely on the assumption that plots are representative of the whole marsh. Edge NECB significantly impacted the $\mathrm{C}$ budget of the whole FC marsh, driving overall net $\mathrm{C}$ losses of $31.5 \times 10^{3} \mathrm{~kg} \mathrm{C}$ year $^{-1}$ despite a significant net $\mathrm{C}$ uptake of $20.6 \times 10^{3} \mathrm{~kg} \mathrm{C}$ year $^{-1}$ using interior rates (83.5 $\mathrm{g} \mathrm{C} \mathrm{m}^{-2}$ year $^{-1}$ ) only extrapolated to the whole marsh. Most estimates of $\mathrm{C}$ accumulation do not make a distinction between edge and interior accumulation rates and, thus, may overestimate $\mathrm{C}$ accumulation for the whole marsh. The net loss of $\mathrm{C}$ from the edge resulted from low sediment $\mathrm{C}$ input and high metabolic rates (Czapla et al., 2020). GPP and R, although nearly balanced at both interior and edge sites, were twofold higher at the edge (Czapla et al., 2020), resulting in higher calculated lateral C export, which was estimated based on measured $\mathrm{R}$.

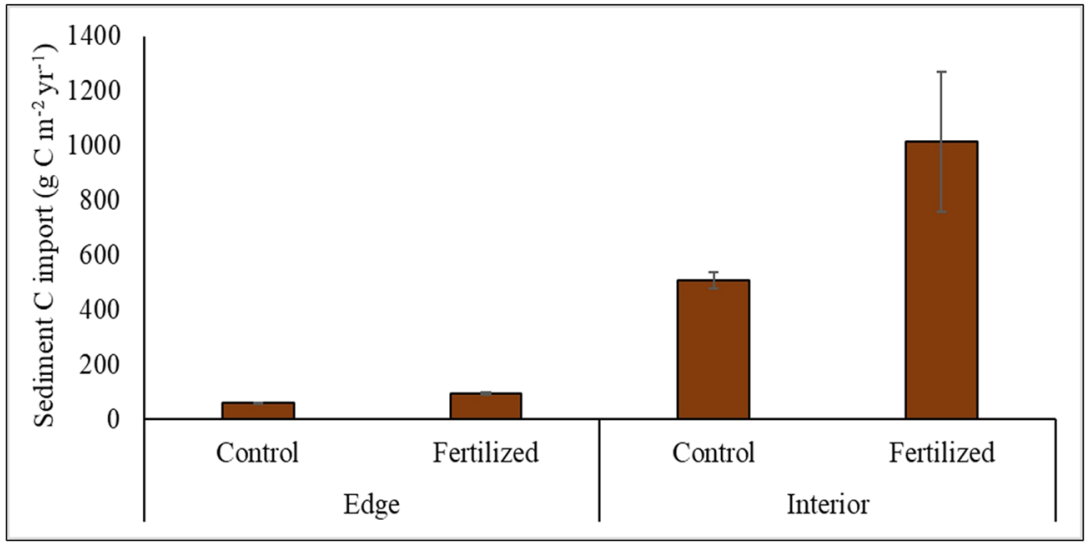

Figure 6. Sediment $C$ import as measured by feldspar marker horizons in the interior and modeled on the edge. Error bars represent standard error of the mean of the three triplicate plots. 
Table 2

Mass Balance Calculation of NECB for Total Freeman Area (Units in $10^{3} \mathrm{~kg}$ ( Year $^{-1}$ )

\begin{tabular}{lccccc}
\hline & \multicolumn{2}{c}{ Edge + interior fluxes } & & \multicolumn{2}{c}{ Interior fluxes only } \\
\cline { 2 - 3 } \cline { 5 - 6 } & Control & \multicolumn{1}{c}{ Fertilized } & & Control & \multicolumn{1}{c}{ Fertilized } \\
\hline NEE & $-0.4(40.6)$ & $-150.1(67.4)$ & & $-9.2(20.2)$ & $-108.2(25.4)$ \\
$F_{\text {DIC }}$ & $-147.3(6.4)$ & $-294.1(12.5)$ & & $-134.7(4.9)$ & $-293.5(1.5)$ \\
$F_{\text {DOC }}$ & $-99.0(5.0)$ & $-214.5(9.9)$ & & $-89.1(3.9)$ & $-214.0(7.0)$ \\
$F_{\text {PC }}$ & $+214.4(19.9)$ & $+427.3(174.5)$ & & $+253.6(23.9)$ & $+508.1(211.5)$ \\
NECB & $-31.5(28.8)$ & $-231.0(44.6)$ & & $+20.6(42.8)$ & $-107.6(68.6)$ \\
\hline
\end{tabular}

Note. $\mathrm{F}_{\mathrm{CH} 4}, \mathrm{~F}_{\mathrm{CO}}$, and $\mathrm{F}_{\mathrm{VOC}}$ were assumed to be negligible relative to other measured $\mathrm{C}$ fluxes. Lateral export includes both tidal and ground water export. This table also includes a comparison of flux calculations without inclusion of edge fluxes. Standard errors are in parentheses. Positive fluxes represent marsh $\mathrm{C}$ loss to the environment; negative values represent marsh $\mathrm{C}$ uptake.
Fertilization had little effect on interior NECB but greatly increased net loss of $\mathrm{C}$ from the edge. In the fertilized interior marsh, $\mathrm{C}$ lost through vertical emissions and lateral $\mathrm{C}$ flux was offset by the increase in allochthonous sediment $\mathrm{C}$ deposition. Similarly, Graham and Mendelsshon (2014) found that higher allochthonous sediment $\mathrm{C}$ inputs due to fertilization balanced out greater losses due to vertical $\mathrm{C}$ emissions. However, on the fertilized edge sediment $\mathrm{C}$ input was insufficient to offset $\mathrm{C}$ losses due to vertical emissions and lateral export. Thus, if this same study were conducted only in marsh interior sites, the negative impact of fertilization on FC marsh $\mathrm{C}$ accumulation would have been greatly underestimated.

A thorough discussion of $\mathrm{FC}$ vertical $\mathrm{C}$ fluxes and their responses to fertilization at these sites were discussed in detail in the companion paper to this work (Czapla et al., 2020).

\subsection{Lateral C Export}

Lateral C export was the most important NECB component for C loss. Groundwater lateral DIC and DOC fluxes were both an order of magnitude lower than the tidal lateral fluxes under control conditions and, thus, less important to overall lateral $\mathrm{C}$ export. While we did not include a fertilized treatment for groundwater lateral export, fertilization at the marsh surface is unlikely to impact groundwater at $50 \mathrm{~cm}$ depth. Although the concentrations of DIC were greater in groundwater than in tidal water, the more rapid rate of tidal water exchange compared to groundwater drainage caused a greater tidal $\mathrm{C}$ export rate relative to groundwater $\mathrm{C}$ export.

Previous studies have observed high variability of tidal C export on short time scales, highlighting the importance of high-frequency measurements of DIC (Chu et al., 2018; Z. A. Wang et al., 2016). Our novel approach for modeling lateral export fluxes was developed to account for variations in water depth, stem height, and respiration rates. This method allowed us to predict the effect of fertilization on lateral export without the need to fertilize an entire marsh area, and may be useful for quickly assessing lateral $\mathrm{C}$ export for marshes when direct measurements are not feasible. Recent lateral $\mathrm{C}$ flux studies relied on high-frequency measurements of DIC in a marsh drainage channel (Z. A. Wang et al., 2016), but these measurements were limited to

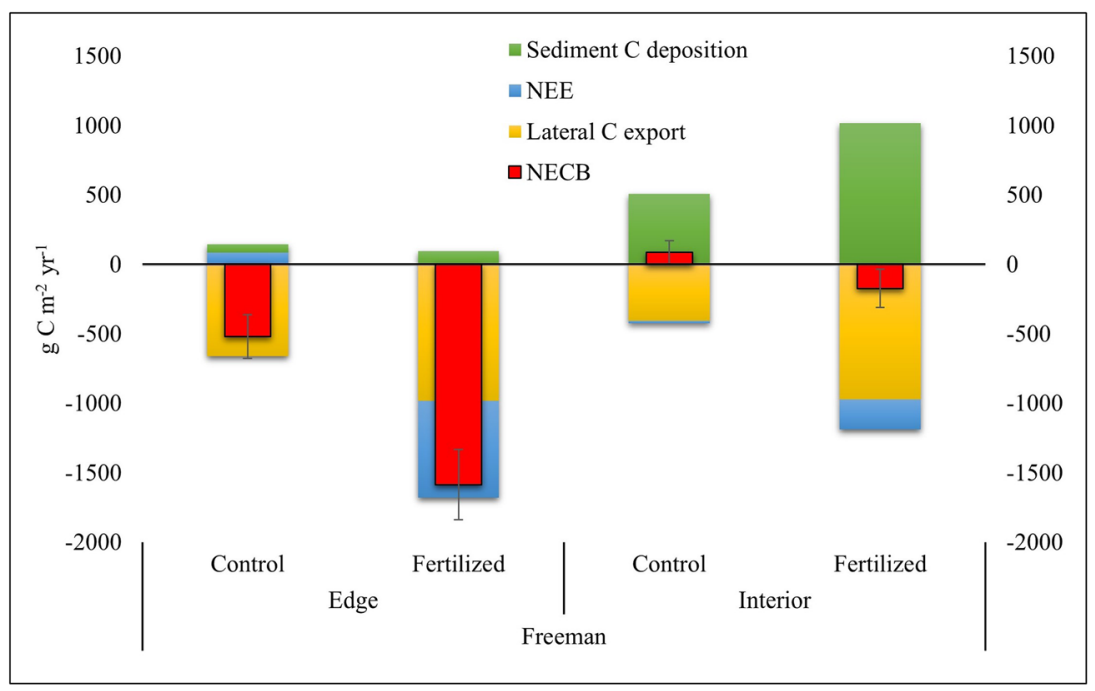

Figure 7. Net ecosystem carbon balance (NECB) per $\mathrm{m}^{2}$ at Freeman Creek marsh based on mass balance. Negative values are fluxes out of the marsh, while positive values are fluxes into the marsh. Error bars represent standard error of the mean of the three triplicate plots. NEE is in the opposite sign previously shown to reflect its negative value in the NECB equation. 

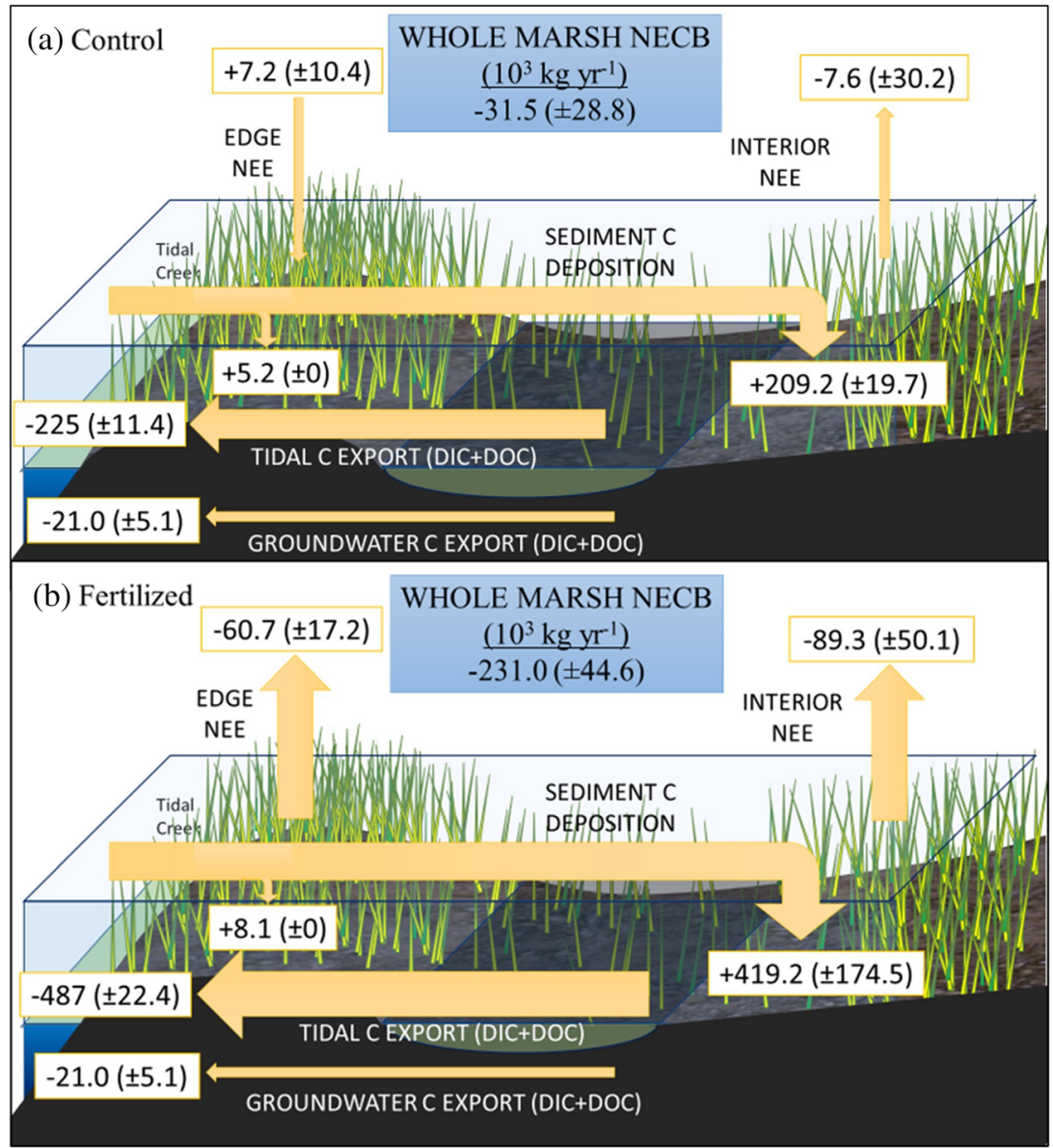

Figure 8. Mass balance of fluxes and total NECB for (a) control and (b) fertilized treatments at Freeman Creek. Positive NECB indicates marsh C uptake, and negative NECB net C loss. Standard errors are in parentheses.

marsh areas with simple single-channel drainage hydrology and may miss higher DIC concentrations produced on the edges of the marsh by high rates of $\mathrm{R}$ and GPP.

Our modeling approach to assessing lateral $\mathrm{C}$ export is subject to uncertainties from a variety of sources. Although the R-predicted lateral DIC fluxes were consistently about $60 \%$ of the directly measured fluxes during two tidal cycles, the lack of statistical difference between R-predicted and measured lateral fluxes suggests that this method is reasonable for lateral export estimation and that the rate of respiration may be assumed to remain unchanged with tidal inundation. While other studies have concluded that tidal inundation inhibits R (Chambers et al., 2013; Guo et al., 2009; Heinsch et al., 2004), these studies were based only on measurements of gaseous $\mathrm{CO}_{2}$ fluxes without considering DIC production. One study that examined the production of both $\mathrm{CO}_{2}$ and DIC in pore water (Tong et al., 2014) concluded that salt marsh R was not significantly different whether the marsh was inundated or not. More rigorous testing of the effects of inundation on total $\mathrm{R}$ (DIC $+\mathrm{CO}_{2}$ flux) may improve the modeling of lateral $\mathrm{C}$ export. This method's accuracy also depended on the ratio of DIC to DOC export, measured only during two seasons at slack flood tide and which may shift seasonally. The direct measurement of lateral $\mathrm{C}$ export during only spring and summer has the potential to bias the DOC export estimation. Our estimates of lateral C export also relied on the accuracy of temporal extrapolations of NEE, which was measured once per season and is likely to have greater error during seasonal transitions.

Despite these potential sources of error, the resulting annual flux per $\mathrm{m}^{2}$ was comparable to that of other studies. Previous studies have reported an average of $421 \pm 250 \mathrm{~g} \mathrm{C} \mathrm{m}^{-2}$ year $^{-1}$ exported laterally on the Atlantic coast (Windham-Myers et al., 2018). DIC comprised $236 \pm 120 \mathrm{~g} \mathrm{C}$ and TOC $185 \pm 71 \mathrm{~g}$ 
$\mathrm{C} \mathrm{m}^{-2}$ year $^{-1}$ of this average (Herrmann et al., 2015; Najjar et al., 2018), indicating similar magnitudes for DIC and TOC fluxes. The majority of TOC export was in the form of DOC because marshes typically import particulate organic carbon (POC). The area-normalized R-predicted lateral fluxes at FC correspond remarkably well to these averages at $227 \mathrm{~g}$ DIC and $178 \mathrm{~g} \mathrm{DOC} \mathrm{m}^{-2}$ year $^{-1}$. Fertilizer increased lateral DIC and DOC export by increasing metabolic rates, implying that increasing anthropogenic $\mathrm{N}$ inputs to salt marsh systems will increase the lateral export of $\mathrm{C}$ to adjacent waters.

\subsection{Sediment Carbon Deposition}

We chose to use marker horizons as the most appropriate way to directly measure short-term sediment deposition. Using other methods for accretion measurement such as ${ }^{210} \mathrm{~Pb},{ }^{14} \mathrm{C}$, ${ }^{137} \mathrm{Cs}$, or Surface Elevation Tables (SETs) accounts for $\mathrm{C}$ accumulation at longer time scales and incorporates processes such as compaction, belowground production, and decomposition. Marker horizons may overestimate sediment $\mathrm{C}$ input due to root growth at the sediment surface, which would result in double-counting of $\mathrm{C}$ from GPP, though this was rarely observed. This study minimized this overestimation by establishing fresh marker horizons seasonally. An overestimate of sediment deposition could also result from applying bulk density measures from sediment cores to the cryocores, which collect the watery, light material at the sediment surface without compaction. The low-lying FC marsh had typical suspended sediment ranges of 20 to $80 \mathrm{mg} \mathrm{L}^{-1}$ and did not exhibit a decrease in suspended sediment concentration of tidal flood water from the edge to the interior marsh (Ensign et al., 2017). Instead, a surface microlayer was resuspended on each tide cycle, which transported suspended sediment well into the marsh (Ensign et al., 2017). As suspended sediment concentrations did not decrease with distance into the marsh, one sediment deposition rate was applied for the whole interior marsh based on marker horizon measurements near the average interior marsh elevation. Extrapolations for sediment input to other marsh interiors may require a correction for distance from the creek.

The $\mathrm{C}$ accumulated through sediment deposition may be used as substrate for microbial respiration, causing the sediment organic $\mathrm{C}$ to be lost as $\mathrm{CO}_{2}$ or DIC and supporting net heterotrophy. Sediment deposition rates for any marsh location are driven by elevation, inundation time, suspended sediment concentrations in overlying tidal water, and AGB (Friedrichs \& Perry, 2001). Edge marsh had much lower sediment deposition rates than the interior resulting from greater elevation and lower inundation time. Fertilization increased sediment deposition in the interior due to higher AGB (see companion paper by Czapla et al., 2020). Although AGB increased on the edge with fertilization, sediment deposition did not increase substantially because of the short inundation time. The large differences between edge and interior rates of sediment deposition and responses to fertilization are important to consider when extrapolating per $\mathrm{m}^{2}$ measurements to the entire marsh. Using only rates measured in the interior marsh will lead to systematic overestimation of sediment $\mathrm{C}$ input in marshes with a high edge berm.

\subsection{Net Ecosystem Carbon Balance}

The fluxes contributing to NECB varied in relative importance across sites and treatments. Lateral C export may be the most uncertain of the components of NECB as previously discussed. Vertical C fluxes were the smallest component of NECB because R and GPP were closely balanced; lateral C fluxes and sediment C import were the major drivers of NECB. NEE demonstrated a small gain or loss under control conditions that shifted to a net $\mathrm{C}$ loss with fertilization. Sediment input represented the greatest gain of $\mathrm{C}$ in the interior, balancing the loss through $\mathrm{NEE}$ and lateral $\mathrm{C}$ export, thereby resulting in a net gain of $\mathrm{C}$ overall. Thus, $\mathrm{FC}$ is a case study that confirms that maintaining suspended sediment concentrations in tidal water is vital to elevation gain and may contribute to marsh $\mathrm{C}$ accumulation.

One might expect NECB estimated by mass balance to be similar to directly measured C accumulation rates (CARs). The CAR measured in 59 Atlantic coast salt marsh sites averaged $126 \pm 87 \mathrm{~g} \mathrm{C} \mathrm{m}^{-2}$ year $^{-1}$ (Ouyang \& Lee, 2014), similar in magnitude to the $83.5 \mathrm{~g} \mathrm{C} \mathrm{m}^{-2}$ year ${ }^{-1} \mathrm{NECB}$ estimated in FC interior control plots. Traps Bay, a marsh within the New River Estuary several miles from FC, was found to have a CAR rate of $167 \mathrm{~g} \mathrm{C} \mathrm{m}^{-2}$ year $^{-1}$ over a 4-year time scale (McTigue et al., 2019). However, CAR is measured using wide variety of methods and interpretations that are difficult to capture with a broad brush. Many are calculated as the surface accretion rate multiplied by the surface C content (Connor et al., 2001; Ford et al., 2012); therefore, it does not account for the carbon accumulated or lost below the surface or in biomass through NEE 
and lateral $\mathrm{C}$ export. Thus, CAR is not always interpreted as an equivalent to total NECB. However, other methods do account for subsurface CAR. Accretion rates used to calculate CAR are measured in a variety of ways, including marker horizons, ${ }^{210} \mathrm{~Pb},{ }^{14} \mathrm{C}$, and ${ }^{137} \mathrm{Cs}$, each of which represent a different time scale (Choi \& Wang, 2004) and may not incorporate all autochthonous $\mathrm{C}$ accumulation deep in the rhizosphere. CAR measured over short-term time scales likely overestimates $\mathrm{C}$ accumulation because it does not factor in degradation processes; CAR estimates tend to decrease as the time scale increases which may be a result of belowground decomposition and compaction (Gonneea et al., 2019). Because many CAR methods only consider $\mathrm{C}$ accumulation via surface accretion, they cannot detect net losses of $\mathrm{C}$ in locations with low accretion rates such as the edge. Inherent error associated with mass balance NECB calculations and estimating CAR at longer time scales may also contribute to differences in these estimates.

It was unexpected that NECB on the edge and for the total marsh area under control conditions would demonstrate a net loss of C. Although the NECB at an annual scale may currently show a net C loss, this does not imply that the entire marsh will destabilize; the loss occurred only on the edges while the interior continued to gain C. Decomposition is generally higher along marsh edges because of greater pore water exchange. As edge berms are built up over long time scales, they reach an elevation at which point they shift from net $\mathrm{C}$ gain to loss as a result of decreasing sediment deposition.

The impact of net $\mathrm{C}$ loss on the edge berm may depend on the source of $\mathrm{C}$ lost, which remains unknown. $\mathrm{C}$ contributing to lateral $\mathrm{C}$ export and net $\mathrm{CO}_{2}$ emission may be composed of a combination of sources such as plant leachates, remineralized sediment C, and BGB, which turns over on the order of every 3 years (Schubauer \& Hopkinson, 1984). To explain how FC marsh edge continues to persist at a high elevation with annual net loss of $\mathrm{C}$, allochthonous or legacy organic $\mathrm{C}$ must be used as a substrate for respiration. About $40 \%$ of the C fixed by GPP has been estimated to be respired by the S. alterniflora plant (Dai \& Wiegert, 1996), and the remainder of the fixed carbon builds and maintains biomass, leaches from plant roots and leaves, and contributes to lateral $\mathrm{C}$ export. A better understanding of what controls organic matter decomposition in sediments is critical to produce realistic mass balances for salt marshes (Mueller et al., 2016; Spivak et al., 2019).

Other $\mathrm{C}$ budget studies have been applied to a broader scale, averaging $\mathrm{C}$ fluxes from different marshes in a limited number of studies and multiplying by the total area to extrapolate $\mathrm{C}$ accumulation to global salt marsh area (Chmura et al., 2003; Ouyang \& Lee, 2014) or lateral C export to the salt marshes of the U.S. east coast (Herrmann et al., 2015; Najjar et al., 2018). However, this study demonstrates the challenges of scaling from per $\mathrm{m}^{2}$ measurements to whole marsh estimates, which likely also applies to broader scale extrapolations. Since ignoring edge differences for marshes even with a low proportion of edge area resulted in significantly different estimates of NECB, edge and interior marsh should be assessed as distinct areas to improve future extrapolations. While edge versus interior likely exemplifies the most extreme contrast between marsh NECB estimates, estimates can be further improved by increasing the resolution of location-specific NECB based on physical or chemical parameters across a marsh.

\section{Conclusions}

1. Lateral $\mathrm{C}$ export may be predicted using respiration rates, stem heights, and water level data.

2. Under natural conditions, lateral $\mathrm{C}$ export and net $\mathrm{C}$ loss were greater on the edge than the interior, but sediment $\mathrm{C}$ input was greater in the interior.

3. Responses of NEE and NECB to fertilization were greater on the edge than the interior.

4. Fertilization increased net $\mathrm{CO}_{2}$ emission, lateral $\mathrm{C}$ export, sediment $\mathrm{C}$ input, and net $\mathrm{C}$ loss for the marsh overall.

5. Accounting for differences in marsh edge versus interior fluxes is crucial for accurate spatial extrapolations, even for marshes with a low proportion of edge area.

\section{Conflict of Interest}

The authors are not aware of any conflicts of interest regarding this manuscript. 


\section{Data Availability Statement}

Raw data used in this study and other DCERP data products are accessible via the DOE Environmental Systems Science Data Infrastructure for a Virtual Ecosystem (ESS-Dive, https://data.ess-dive.lbl.gov/view/ https://doi.org/10.15485/1602783).

\section{Acknowledgments}

This research was conducted under the Defense Coastal/Estuarine Research Program (DCERP), funded by the Strategic Environmental Research and Development Program (SERDP) of the Department of Defense. Views, opinions, and/or findings contained in this report are those of the authors and should not be construed as an official U.S. Department of Defense position or decision unless so designated by other official documentation. The authors worked in collaboration with our colleagues in the NOAA Beaufort Lab, including Jenny Davis, Nathan McTigue, Anna Hilting, Quentin Walker, Mike Greene, and Luke Snedaker, who provided the use of the greenhouse gas analyzer, performed the seasonal plot fertilizations, gathered and QC'd water level data, and installed marsh boardwalks. The scientific results and conclusions, as well as any views or opinions expressed herein, are those of the author(s) and do not necessarily reflect the views of NOAA or the Department of Commerce. Many thanks to Susan Cohen, our liaison to the Marine Corps Base Camp Lejeune. This study could not have been done without Hunter Walker, who contributed much assistance, including building parts of the static chamber system, driving the boat to the site, and helping sample during every field campaign. Many thanks to others who helped with seasonal field campaigns: Jen Stanhope, Miguel Semedo, Shanna Williamson, Bryce Van Dam, and Scott Ensign. Thanks also to Mark Brush, Bongkeun Song, Anne Giblin, Annie Murphy, and Ashley Smyth for their many helpful suggestions that improved this study. This is Contribution No. 3936 of the Virginia Institute of Marine Science, William \& Mary.

\section{References}

Anisfeld, S. C., \& Hill, T. D. (2012). Fertilization effects on elevation change and belowground carbon balance in a Long Island Sound tidal marsh. Estuaries and Coasts, 35(1), 201-211. https://doi.org/10.1007/s12237-011-9440-4

Bates, D., Maechler, M., Bolker, B., \& Walker, S. (2015). lme4: Linear mixed-effects models using Eigen and S4. R package version 1.1-8, Bradley, P. M., \& Morris, J. T. (1990). Influence of oxygen and sulfide concentration on nitrogen uptake kinetics in Spartina alterniflora. Ecology, 71(1), 282-287. https://doi.org/10.2307/1940267

Cahoon, D. R., \& Reed, D. J. (1995). Relationships among marsh surface topography, hydroperiod, and soil accretion in a deteriorating Louisiana salt marsh. Journal of Coastal Research, 11(2), 357-369.

Caplan, J. S., Hager, R. N., Megonigal, J. P., \& Mozdzer, T. J. (2015). Global change accelerates carbon assimilation by a wetland ecosystem engineer. Environmental Research Letters, 10(11), 115006. https://doi.org/10.1088/1748-9326/10/11/115006

Chambers, L. G., Osborne, T. Z., \& Reddy, K. R. (2013). Effect of salinity-altering pulsing events on soil organic carbon loss along an intertidal wetland gradient: A laboratory experiment. Biogeochemistry, 115(1-3), 363-383. https://doi.org/10.1007/s10533-0139841-5

Chapin, F. S., Woodwell, G. M., Randerson, J. T., Rastetter, E. B., Lovett, G. M., Baldocchi, D. D., et al. (2006). Reconciling carbon-cycle concepts, terminology, and methods. Ecosystems, 9(7), 1041-1050. https://doi.org/10.1007/s10021-005-0105-7

Childers, D. L., Day, J. W., \& Mckellar, H. N. (2002). Twenty more years of marsh and estuarine flux studies: Revisiting Nixon (1980). In M. P. Weinstein, \& D. A. Kreeger (Eds.), Concepts and controversies in tidal marsh ecology (pp. 391-423). Dordrecht: Springer. https://doi. org/10.1007/0-306-47534-0_18

Chmura, G. L., Anisfeld, S. C., Cahoon, D. R., \& Lynch, J. C. (2003). Global carbon sequestration in tidal, saline wetland soils. Global Biogeochemical Cycles, 17(4), 1111. https://doi.org/10.1029/2002GB001917

Choi, Y., \& Wang, Y. (2004). Dynamics of carbon sequestration in a coastal wetland using radiocarbon measurements: Dynamics of carbon sequestration. Global Biogeochemical Cycles, 18, GB4016. https://doi.org/10.1029/2004GB002261

Chu, S. N., Wang, Z. A., Gonneea, M. E., Kroeger, K. D., \& Ganju, N. K. (2018). Deciphering the dynamics of inorganic carbon export from intertidal salt marshes using high-frequency measurements. Marine Chemistry, 206, 7-18. https://doi.org/10.1016/j.marchem.2018.08.005

Connor, R. F., Chmura, G. L., \& Beecher, C. B. (2001). Carbon accumulation in Bay of Fundy salt marshes: Implications for restoration of reclaimed marshes. Global Biogeochemical Cycles, 15, 943-954. https://doi.org/10.1029/2000gb001346

Czapla, K. M., Anderson, I. C, \& Currin, C. A. (2020). The effect of fertilization on biomass and metabolism in North Carolina salt marshes: Modulated by location-specific factors. Journal of Geophysical Research: Biogeosciences, 125, e2019JG005238. https://doi.org/10.1029/ 2019JG005238

Dai, T., \& Wiegert, R. G. (1996). Estimation of the primary productivity of Spartina alterniflora using a canopy model. Ecography, 19(4), 410-423. https://doi.org/10.1111/j.1600-0587.1996.tb00252.x

Darby, F. A., \& Turner, R. E. (2008). Effects of eutrophication on salt marsh root and rhizome biomass accumulation. Marine Ecology Progress Series, 363, 63-70. https://doi.org/10.3354/meps07423

Darke, A. K., \& Megonigal, J. P. (2003). Control of sediment deposition rates in two mid-Atlantic Coast tidal freshwater wetlands. Estuarine, Coastal and Shelf Science, 57(1-2), 255-268. https://doi.org/10.1016/S0272-7714(02)00353-0

Davis, J., Currin, C., \& Morris, J. T. (2017). Impacts of fertilization and tidal inundation on elevation change in microtidal, low relief salt marshes. Estuaries and Coasts, 40(6), 1677-1687. https://doi.org/10.1007/s12237-017-0251-0

Deegan, L. A., Johnson, D. S., Warren, R. S., Peterson, B. J., Fleeger, J. W., Fagherazzi, S., \& Wollheim, W. M. (2012). Coastal eutrophication as a driver of salt marsh loss. Nature, 490(7420), 388-392. https://doi.org/10.1038/nature11533

Duarte, C. M., Middelburg, J. J., \& Caraco, N. (2005). Major role of marine vegetation on the oceanic carbon cycle. Biogeosciences, 2(1), 1-8. https://doi.org/10.5194/bg-2-1-2005

Ensign, S., Currin, C., Piehler, M., \& Tobias, C. (2017). A method for using shoreline morphology to predict suspended sediment concentration in tidal creeks. Geomorphology, 276, 280-288. https://doi.org/10.1016/j.geomorph.2016.09.036

Ford, H., Garbutt, A., Jones, L., \& Jones, D. L. (2012). Methane, carbon dioxide and nitrous oxide fluxes from a temperate salt marsh: Grazing management does not alter Global Warming Potential. Estuarine, Coastal and Shelf Science, 113, 182-191. https://doi.org/ 10.1016/j.ecss.2012.08.002

Friedrichs, C. T., \& Perry, J. E. (2001). Tidal salt marsh morphodynamics: A synthesis. Journal of Coastal Research, $27,7-37$.

Gardner, L. R. (2005). A modeling study of the dynamics of pore water seepage from intertidal marsh sediments. Estuarine, Coastal and Shelf Science, 62(4), 691-698. https://doi.org/10.1016/j.ecss.2004.10.005

Geoghegan, E. K., Caplan, J. S., Leech, F. N., Weber, P. E., Bauer, C. E., \& Mozdzer, T. J. (2018). Nitrogen enrichment alters carbon fluxes in a New England salt marsh. Ecosystem Health and Sustainability, 4(11), 277-287. https://doi.org/10.1080/20964129.2018.1532772

Gonneea, M. E., Maio, C. M., Kroeger, K. D., Hawkes, A. D., Mora, J., Sullivan, R., et al. (2019). Salt marsh ecosystem restructuring enhances elevation resilience and carbon storage during accelerating sea-level rise. Estuarine, Coastal and Shelf Science, $217,56-68$. https://doi.org/10.1016/j.ecss.2018.11.003

Graham, S. A., \& Mendelsshon, I. A. (2014). Coastal wetland stability maintained through counterbalancing accretionary responses to chronic nutrient enrichment. Ecology, 95(12), 3271-3283. https://doi.org/10.1890/14-0196.1

Graham, S. A., \& Mendelsshon, I. A. (2016). Contrasting effects of nutrient enrichment on below-ground biomass in coastal wetlands. Ecology, 104(1), 249-260. https://doi.org/10.1111/1365-2745.12498

Guo, H., Noormets, A., Zhao, B., Chen, J., Sun, G., Gu, Y., et al. (2009). Tidal effects on net ecosystem exchange of carbon in an estuarine wetland. Agricultural and Forest Meteorology, 149(11), 1820-1828. https://doi.org/10.1016/j.agrformet.2009.06.010

Harvey, J. W., Chambers, R. M., \& Hoelscher, J. R. (1995). Preferential flow and segregation of porewater solutes in wetland sediment. Estuaries, 18(4), 568-578. https://doi.org/10.2307/1352377 
Heinsch, F. A., Heilman, J. L., McInnes, K. J., Cobos, D. R., Zuberer, D. A., \& Roelke, D. L. (2004). Carbon dioxide exchange in a high marsh on the Texas Gulf Coast: Effects of fresh water availability. Agricultural and Forest Meteorology, 125(1-2), 159-172. https://doi.org/ 10.1016/j.agrformet.2004.02.007

Herrmann, M., Najjar, R. G., Kemp, W. M., Alexander, R. B., Boyer, E. W., Cai, W.-J., et al. (2015). Net ecosystem production and organic carbon balance of U.S. east coast estuaries: A synthesis approach. Global Biogeochemical Cycles, 29, 96-111. https://doi.org/10.1002/ 2013gb004736

Hopkinson, C. S., Cai, W. J., \& Hu, X. (2012). Carbon sequestration in wetland dominated coastal systems-A global sink of rapidly diminishing magnitude. Current Opinion in Environmental Sustainability, 4(2), 186-194. https://doi.org/10.1016/j.cosust.2012.03.005

Howes, B. L., \& Goehringer, D. D. (1994). Porewater drainage and dissolved organic carbon and nutrient losses through the intertidal creekbanks of a New England salt marsh. Marine Ecology Progress Series, 114(3), 289-301. https://doi.org/10.3354/meps114289

Johnson, D. S., Warren, R. S., Deegan, L. A., \& Mozdzer, T. J. (2016). Saltmarsh plant responses to eutrophication. Ecological Applications, 26(8), 2649-2661. https://doi.org/10.1002/eap.1402

Kirwan, M. L., \& Mudd, S. M. (2012). Response of salt-marsh carbon accumulation to climate change. Nature, 489(7417), 550-553. https:// doi.org/10.1038/nature11440

Kirwan, M. L., Temmerman, S., Skeehan, E. E., Guntenspergen, G. R., \& Fagherazzi, S. (2016). Overestimation of marsh vulnerability to sea level rise. Nature Climate Change, 6, 253-260. https://doi.org/10.1038/nclimate2909

Lettrich, M. (2011). Nitrogen advection and denitrification loss in southeastern North Carolina salt marshes. Master's thesis. University of North Carolina, Wilmington, NC.

McFarlin, C. R., Brewer, J. S., Buck, T. L., \& Pennings, S. C. (2008). Impacts of fertilization on a salt marsh food web in Georgia. Estuaries and Coasts, 31(2), 313-325. https://doi.org/10.1007/s12237-008-9036-9

McTigue, N., Davis, J., Rodriguez, T., McKee, B., Atencio, A., \& Currin, C. (2019). Sea-level rise explains changing carbon accumulation rates in a salt marsh over the past two millennia. Journal of Geophysical Research: Biogeosciences, 124, 2945-2957. https://doi.org/ 10.1029/2019JG005207

Mendelssohn, I. A. (1979). Influence of nitrogen level, form, and application method on the growth-response of Spartina alterniflora in North Carolina. Estuaries, 2(2), 106-112. https://doi.org/10.2307/1351634

Morris, J. T., Barber, D. C., Callaway, J. C., Chambers, R., Hagen, S. C., Hopkinson, C. S., et al. (2016). Contributions of organic and inorganic matter to sediment volume and accretion in tidal wetlands at steady state. Earth's Future, 4, 110-121. https://doi.org/10.1002/ 2015EF000334

Morris, J. T., Shaffer, G. P., \& Nyman, J. A. (2013). Brinson Review: Perspectives on the influence of nutrients on the sustainability of coastal wetlands. Wetlands, 33, 975-988. https://doi.org/10.1007/s13157-013-0480-3

Morris, J. T., Sundareshwar, P. V., Nietch, C. T., Kjerfve, B., \& Cahoon, D. R. (2002). Responses of coastal wetlands to rising sea level. Ecology, 83(10), 2869-2877. https://doi.org/10.1890/0012-9658(2002)083[2869:ROCWTR]2.0.CO;2

Morris, J. T., Sundberg, K., \& Hopkinson, C. S. (2013). Salt marsh primary production and its responses to relative sea level and nutrients in estuaries at Plum Island, Massachusetts, and North Inlet, South Carolina, USA. Oceanography, 26(3), 78-84. https://doi.org/10.5670/ oceanog.2013.48

Mueller, P., Jensen, K., \& Megonigal, J. P. (2016). Plants mediate soil organic matter decomposition in response to sea level rise. Global Change Biology, 22(1), 404-414. https://doi.org/10.1111/gcb.13082

Najjar, R. G., Herrmann, M., Alexander, R., Boyer, E. W., Burdige, D. J., Butman, D., et al. (2018). Carbon budget of tidal wetlands, estuaries, and shelf waters of Eastern North America. Global Biogeochemical Cycles, 32, 389-416. https://doi.org/10.1002/ $2017 \mathrm{gb} 005790$

Neubauer, S. C. (2008). Contributions of mineral and organic components to tidal freshwater marsh accretion. Estuarine, Coastal and Shelf Science, 78(1), 78-88. https://doi.org/10.1016/j.ecss.2007.11.011

Neubauer, S. C., \& Anderson, I. C. (2003). Transport of dissolved inorganic carbon from a tidal freshwater marsh to the York River estuary. Limnology and Oceanography, 48(1), 299-307. https://doi.org/10.4319/lo.2003.48.1.0299

Nixon, S. W. (1980). Between coastal marshes and coastal waters-A review of twenty years of speculation and research on the role of salt marshes in estuarine productivity and water chemistry. In P. Hamilton, \& K. B. MacDonald (Eds.), Estuarine and wetland processes (pp. 437-525). New York: Plenum. https://doi.org/10.1007/978-1-4757-5177-2_20

Odum, E. P. (1980). The status of three ecosystem-level hypotheses 'regarding salt marsh estuaries: Tidal subsidy, outwelling and detritusbased food chains. In V. Kennedy (Ed.), Estuarine perspectives (pp. 485-495). New York: Academic Press.

Ouyang, X., \& Lee, S. Y. (2014). Updated estimates of carbon accumulation rates in coastal marsh sediments. Biogeosciences, 11(18), 5057-5071. https://doi.org/10.5194/bg-11-5057-2014

Pardo, L. H., Fenn, M. E., Goodale, C. L., Geiser, L. H., Driscoll, C. T., Allen, E. B., et al. (2011). Effects of nitrogen deposition and empirical nitrogen critical loads for ecoregions of the United States. Ecological Applications, 21(8), 3049-3082. https://doi.org/ 10.1890/10-2341.1

Poffenbarger, H. J., Needelman, B. A., \& Megonigal, J. P. (2011). Salinity influence on methane emissions from tidal marshes. Wetlands, 31(5), 831-842. https://doi.org/10.1007/s13157-011-0197-0

R Core Team (2014). R: A language and environment for statistical computing. R Foundation for Statistical Computing, Vienna, Austria URL http://www.R-project.org/

Rogers, K., Kelleway, J. J., Saintilan, N., Megonigal, J. P., Adams, J. B., Holmquist, J. R., et al. (2019). Wetland carbon storage controlled by millennial-scale variation in relative sea level rise. Nature, 567(7746), 91-95. https://doi.org/10.1038/s41586-019-0951-7

Schubauer, J. P., \& Hopkinson, C. S. (1984). Above- and belowground emergent macrophyte production turnover in a coastal marsh ecosystem, Georgia. Limnology and Oceanography, 29(5), 1052-1065. https://doi.org/10.4319/lo.1984.29.5.1052

Spivak, A. C., Sanderman, J., Bowen, J. L., Canuel, E. A., \& Hopkinson, C. S. (2019). Nature Geoscience, 12(9), 685-692. https://doi.org/ 10.1038/s41561-019-0435-2

Temmerman, S., Govers, G., Wartel, S., \& Meire, P. (2003). Spatial and temporal factors controlling short-term sedimentation in a salt and freshwater tidal marsh, Scheldt estuary, Belgium, SW Netherlands. Earth Surface Processes and Landforms, 28(7), 739-755. https://doi. org/10.1002/esp.495

Tong, C., Wang, C., Huang, J. F., Wang, W. Q., Liao, J., \& Yao, C. (2014). Ecosystem respiration does not differ before and after tidal inundation in brackish marshes of the Min River estuary, Southeast China. Wetlands, 34(2), 225-233. https://doi.org/10.1007/s13157013-0478-x

Valiela, I. (2015). The Great Sippewissett salt marsh plots-Some history, highlights, and contrails from a long-term study. Estuaries and Coasts, 38(4), 1099-1120. https://doi.org/10.1007/s12237-015-9976-9 
Wakeham, S. G., Davis, A. C., \& Goodwin, J. T. (1982). Biogeochemistry of volatile organic compounds in marine experimental ecosystems and the estuarine environment-initial results. In G. D. Grice, \& M. R. Reeve (Eds.), Marine mesocosms (pp. 137-151). New York, NY: Springer. https://doi.org/10.1007/978-1-4612-5645-8_10

Wang, J., Zhu, T., Ni, H., Zhong, H., Fu, X., \& Wang, J. (2013). Effects of elevated $\mathrm{CO}_{2}$ and nitrogen deposition on ecosystem carbon fluxes on the Sanjiang plain wetland in Northeast China. PLoS ONE, 8(6), e66563. https://doi.org/10.1371/journal.pone.0066563

Wang, Z. A., Kroeger, K. D., Ganju, N. K., Gonneea, M. E., \& Chu, S. N. (2016). Intertidal salt marshes as an important source of inorganic carbon to the coastal ocean. Limnology and Oceanography, 61(5), 1916-1931. https://doi.org/10.1002/lno.10347

Wigand, C., Brennan, P., Stolt, M., Holt, M., \& Ryba, S. (2009). Soil respiration rates in coastal marshes subject to increasing watershed nitrogen loads in southern New England, USA. Wetlands, 29(3), 952-963. https://doi.org/10.1672/08-147.1

Wigand, C., Roman, C. T., Davey, E., Stolt, M., Johnson, R., Hanson, A., et al. (2014). Below the disappearing marshes of an urban estuary: Historic nitrogen trends and soil structure. Ecological Applications, 24(4), 633-649. https://doi.org/10.1890/13-0594.1

Windham-Myers, L., Cai, W.-J., Alin, S., \& Andersson, J. (2018). Second state of the carbon cycle report: Chapter 15 Tidal wetlands and estuaries. https://doi.org/10.7930/SOCCR2.2018.Ch15

Zawatski, M. (2018). Carbon exchange and sediment deposition in a heterogeneous New England salt marsh (Master's thesis). Villanova, PA, USA: Villanova University. 